\title{
KETAHANAN PANGAN KELUARGA PESERTA PROGRAM PEMBERDAYAAN MASYARAKAT DI PEDESAAN
}

\author{
(The Food Security of The Family Participant in \\ Community Empowerment Program At Rural Area)
}

\author{
Tin Herawati ${ }^{1 *}$, Basita Ginting S², Pang S. Asngari ${ }^{2}$, Djoko Susanto ${ }^{2}$, dan Herien Puspitawati ${ }^{1}$ \\ ${ }^{1}$ Departemen Ilmu Keluarga dan Konsumen, Fakultas Ekologi Manusia, Institut Pertanian Bogor, Bogor \\ 16680 \\ 2 Departemen Sains Komunikasi dan Pengembangan Masyarakat \\ * Alamat korespondensi : Departemen IImu Keluarga dan Konsumen, Fakultas Ekologi Manusia, Institut \\ Pertanian Bogor, Bogor 16680. Email: gmsk_29@yahoo.com
}

\begin{abstract}
ABST RACT
The research objectives were to analyzed the family food security and its factors of the participants in the community empowerment program at rural area. The research design was crossectional study and the data collection technique used a survey method toward 300 families, and their specification were 140 families from the National Program of Community Empowerment (PNPM), 107 families from The Keluarga Harapan Program (PKH), 31 families from the Raksa Desa Program and 22 families from The Business Development Program of Rural Agribusiness (PUAP). The highest percentage (52.0\%) of the family categorized into food vulnerable and as many as 37.3 percent was insecure category. It was found 10.7 percent families categorized into secure category. Base on the program, more than a half families of PKH group (50.5\%) and PUAP (63.6\%) are insecure category. Food vulnerable category is in PNPM group (60.0\%) and Raksa Desa group (61.3\%). The highest percentage (15.0\%) thar categorized into secure category is in PNPM group. The factors which influence significantly toward the family food security are the income per capita, the family size and the asset.
\end{abstract}

Key words: food security, community empowerment program, rural area

\section{PENDAHULUAN}

Pada saat ini Indonesia masih dihadapkan pada berbagai permasalahan diantaranya status gizi kurang dan buruk pada anak balita serta kematian bayi dan ibu yang masih tinggi. Pada tahun 2006, jumlah anak balita yang memiliki status gizi kurang dan buruk adalah 4.28 juta anak, dan 944246 orang di antaranya berisiko gizi buruk. Pada tahun 2007, jumlah anak balita bergizi kurang dan buruk menurun menjadi 4.13 juta anak, dan 755397 orang diantaranya tergolong risiko gizi buruk (Bappenas 2008). Menurut Dinas Kesehatan Jawa Barat, pada tahun 2009 terdapat 1.01 persen anak balita menderita gizi buruk dari 3536981 anak balita dan anak yang menderita gizi kurang mencapai 380673 (Cahyadi 2009). Angka kematian bayi di Indonesia pada tahun 2006 yaitu 35 per seribu kelahiran hidup dan angka kematian ibu sebesar 307 per seratus ribu kelahiran hidup. Laporan BPS menyebutkan angka kematian ibu pada tahun 2007 menurun menjadi 228 per seratus ribu kelahiran, sedangkan kematian bayi masih tetap yaitu 35 per seribu kelahiran hidup (Supari 2008). Meskipun terjadi pe-nurunan angka kematian ibu dan bayi, tetapi jumlah tersebut masih tertinggi di negara ASEAN.

Permasalahan gizi dan kesehatan di Indonesia erat kaitannya dengan kemiskinan. Permasalahan kesehatan dan gizi sering dialami oleh anak-anak usia dini yang berasal dari keluarga tidak mampu dan tinggal di wilayah perdesaan (Cahyadi 2009). Pada tahun 2009, sebanyak 63.41 persen penduduk miskin berada di pedesaan, sedangkan pada tahun 2010 jumlah tersebut bertambah menjadi 64.23 persen. Kondisi tersebut menunjukkan bahwa kemiskinan masih menjadi potret dominan di pedesaan (BPS 2010). Kemiskinan menyebabkan banyak keluarga mengalami kesulitan dalam menjalani kehidupan yang layak, sehingga pemenuhan kebutuhan pendidikan, kesehatan dan pangan menjadi tidak memadai dan sebagai akibatnya pembentukan sumber daya manusia yang berkualitas menjadi tidak optimal.

Status gizi selain merupakan prediktor yang baik untuk mortalitas dan morbiditas, juga merupakan refleksi dari situasi pangan maupun situasi ekonomi (Sudiman 2008). Berbagai kajian membutktikan bahwa status 
gizi yang baik sangat ditentukan oleh jumlah asupan pangan yang bermutu. Rendahnya pendapatan menyebabkan rendahnya daya beli keluarga terhadap kebutuhan pangan seharihari, sehingga terbatasnya kualitas dan kuantitas pangan yang dikonsumsi (Cahyadi 2009). Adanya keterkaitan yang erat antara status gizi dan situasi pangan, maka memunculkan suatu pertanyaan bagaimana kondisi ketahanan pangan keluarga, terutama keluarga di pedesaan yang menjadi potret kemiskinan.

Pemberdayaan masyarakat merupakan program penanggulangan masalah kemiskinan dan menjadi salah satu program prioritas pembangunan. Program pemberdayaan masyarakat banyak dibentuk sebagai upaya pemerintah mengatasi masalah krisis ekonomi yang dimulai tahun 1997. Adanya pemberdayaan masyarakat miskin di perdesaan, diharapkan dapat memenuhi kesejahteraan hidup keluarga, khususnya balita, baik itu berupa pangan, kesehatan, dan pendidikan. Dengan terpenuhinya kesejahteraan hidup, maka kehilangan generasi penerus bangsa (loss generation) dapat dihindari.

Tujuan umum penelitian adalah menganalisis ketahanan pangan keluarga peserta program pemberdayaan masyarakat di perdesaan. Tujuan khusus (1) mengetahui karakteristik keluarga; (2) menganalisis ketahanan pangan keluarga; (3) menganalisis faktor-faktor yang mempengaruhi ketahanan pangan keluarga.

\section{METODE}

\section{Desain dan Lokasi}

Desain penelitian adalah crossectional study dan teknik pengumpulan data dilakukan dengan metode survei. Lokasi penelitian di Kecamatan Dramaga, Leuwisadeng, dan Pamijahan, Kabupaten Bogor. Pemilihan lokasi dilakukan secara purposive, dengan pertimbangan (1) Kabupaten Bogor masih menempati jumlah penduduk miskin tertinggi di J awa Barat selama priode 2006-2009; (2) Tingkat kemiskinan di Kabupaten Bogor yang terus meningkat selama periode 2007-2009; dan (3) Kabupaten Bogor terdapat beberapa program pemberdayaan yang dilaksanakan oleh berbagai pihak yaitu pemerintah, swasta dan perguruan tinggi. Pemilihan kecamatan dilakukan secara purposif dengan kriteria tingkat kemiskinan yang cukup tinggi (lebih dari 40 persen) dan terdapat lebih dari satu program kegiatan pemberdayaan. Waktu penelitian dilaksanakan selama delapan bulan, terhitung mulai bulan Februari-Oktober 2010.

\section{Cara Pemilihan Sampel}

Populasi penelitian adalah seluruh keluarga peserta pemberdayaan masyarakat di tiga kecamatan. Sampel penelitian adalah keluarga peserta program pemberdayaan masyarakat dan telah menjadi peserta program minimal satu tahun. Teknik pengambilan sampel adalah stratified propotional random sampling. J umlah sampel yang diambil yaitu 300 keluarga, dengan rincian 140 keluarga dari program Program Nasional Pembedayaan Masyarakat (PNPM), 107 ke-luarga dari Program Keluarga Harapan (PKH), 31 keluarga dari Program Raksa Desa dan 22 dari program Pengembangan Usaha Agribisnis Perdesaan (PUAP).

\section{J enis dan Cara Pengumpulan Data}

Jenis data yang dikumpulkan terdiri dari data primer dan sekunder. Data primer dikumpulkan melalui wawancara menggunakan kuesioner, terdiri dari (1) karakteristik keluarga; dan (2) ketahanan pangan keluarga. Indikator dan skala data dari masing-masing peubah dapat dilihat pada Tabel 1. Data sekunder diperoleh dari kantor kelurahan setempat, Badan Pemberdayaan Masyarakat Perdesaan (BPMD) Kabupaten Bogor dan sekretariat program pemberdayaan di masing-masing kecamatan. Data sekunder yang diambil dalam penelitian tingkat kemiskinan dan jumlah penerima manfaat program pemberdayaan.

Pengukuran ketahanan pangan keluarga pada penelitian ini mengacu FAO (1996) dan Purwantini et al. (2001). Indikator ketahanan pangan yang digunakan adalah ketersediaan pangan pokok, stabilitas ketersediaan pangan, kualitas pangan dan tingkat konsumsi energi keluarga.

\section{Ketersediaan Pangan Pokok}

Menurut Pusat Penelitian Kependudukan (PPK) LIPI (2004) ketersediaan pangan di rumah tangga mengacu pada pangan yang cukup dan tersedia dalam jumlah yang dapat memenuhi kebutuhan konsumsi rumah tangga. Hasil penelitian Varendra (2007) menunjukkan bahwa pembelian pangan pokok bersifat harian sangat rentan dengan perubahan harga. Mengacu pada pendapatan tersebut maka pembelian pangan pokok bersifat harian tidak menjamin ketersediaannya, terutama pada keluarga miskin, dibandingkan mingguan dan bulanan. Oleh karena itu pengukuran keter- 
sediaan pangan pokok keluarga didekati dengan kebiasaan membeli pangan pokok (harian, mingguan atau bulanan).

Tabel 1. Peubah, Indikator dan Skala Data yang Digunakan dalam Penelitian

\begin{tabular}{lll}
\hline \multicolumn{1}{c}{ Peubah } & \multicolumn{1}{c}{ Indikator } & Skala Data \\
\hline Karakteristik & $\begin{array}{l}\text { Pendidikan suami dan } \\
\text { istri (thn) }\end{array}$ & Rasio \\
& $\begin{array}{l}\text { Pekerjaan suami dan } \\
\text { istri }\end{array}$ & Nominal \\
& $\begin{array}{l}\text { Umur suami (thn) } \\
\text { Jumlah Anggota } \\
\text { keluarga (orang) }\end{array}$ & Rasio \\
& Rasio \\
& Pendapatan (Rp) & Rasio \\
Ketahanan & $\begin{array}{l}\text { Ketersediaan } \\
\text { Pecukupan pangan }\end{array}$ & Ordinal \\
& $\begin{array}{l}\text { Stabilitas ketersediaan } \\
\text { pangan }\end{array}$ & Ordinal \\
& Kualitas pangan & Ordinal \\
& Tingkat konsumsi energi \\
keluarga & Rasio \\
\hline
\end{tabular}

Stabilitas Ketersediaan Pangan

Salah satu indikator yang digunakan untuk mengukur stabilitas ketersediaan pangan di tingkat rumah tangga adalah frekuensi makan anggota rumah tangga dalam sehari (PPK-LIPI 2004). Berdasarkan hal tersebut maka stabilitas ketersediaan pangan diukur berdasarkan frekunsi makan (1 kali, 2 kali atau 3 kali).

\section{Kualitas Pangan}

Ukuran kualitas pangan dilihat dari keragaman dan kualitas pangan yang dikonsumsi (PPK-LIPI 2004). Pada penelitian ini, data diperoleh dengan metode recall $1 \times 24$ jam. Berdasarkan hal tersebut maka kualitas pangan keluarga dibagi menjadi tiga kategori yaitu:

(1) Kualitas pangan yang tidak baik atau tidak beragam jika makanan yang dikonsumsi terdiri dari pangan pokok dan protein hewani saja atau nabati saja, atau pangan pokok dan sayur saja.

(2) Kualitas pangan yang kurang baik atau kurang beragam jika makanan yang dikonsumsi oleh keluarga kurang beragam yang terdiri dari pangan pokok, protein hewani (berupa ikan asin) saja atau nabati saja (tahu atau tempe) dan sayur.

(3) Kualitas pangan baik atau beragam jika makanan yang dikonsumsi oleh keluarga beragam yang terdiri dari pangan pokok, protein hewani (ikan segar atau pindang, telur, ayam, daging sapi), protein nabati (tahu atau tempe), sayur, dan buah atau tanpa buah.

\section{Tingkat Konsumsi Gizi Keluarga}

Pada penelitian ini indikator yang digunakan untuk mengukur tingkat konsumsi gizi keluarga dihitung berdasarkan asupan energi perkapita dibandingkan dengan angka kecukupan energi (AKE). Selanjutnya tingkat konsumsi energi dikategorikan menjadi tiga kelompok yaitu baik/ cukup $\$ 100 \%$ AKE), kurang (70-99\%AKE), dan sangat kurang ( $<70 \% \mathrm{AKE})$.

\section{Pengolahan dan Analisis Data}

Data penelitian diolah secara statistik deskriptif dan statistik inferensia. Data dianalisis secara deskriptif untuk menggambarkan karakteristik keluarga, dan ketahanan pangan keluarga. Analisis regresi linier berganda digunakan untuk melihat faktor-faktor yang berpengaruh terhadap ketahanan pangan keluarga.

\section{HASIL DAN PEMBAHASAN}

\section{Karakteristik Keluarga}

Secara keseluruhan rata-rata umur istri adalah 37.49 tahun dan umur suami 43.75 tahun. Rata-rata umur istri dan suami masih termasuk usia produktif, sedangkan menurut Hurlock (1980) rata-rata usia istri termasuk dewasa muda dan suami termasuk dewasa madya. Hasil uji statistik menunjukkan tidak terdapat perbedaan signifikan umur istri diantara kelompok pemberdayaan $(p<0.05)$ dan adanya perbedaan yang signifikan antara umur suami pada kelompok PNPM dan PKH $(p \varangle 0.05)$.

Rata-rata jumlah anggota keluarga 5 orang, menurut BKKBN (1996) jumlah tersebut termasuk kategori sedang. Hasil uji statistik menunjukkan adanya perbedaan yang signifikan antara rata-rata jumlah anggota keluarga pada kelompok PKH dengan kelompok PNPM dan PUAP $(p<0.05)$. Rata-rata lama pendidikan istri 5.8 tahun dan suami 6.3 tahun. Hal tersebut menunjukkan tingkat pendidikan istri maupun suami termasuk rendah.

J ika dibandingkan dengan indikator garis kemiskinan Kabupaten Bogor tahun 2009 maka 41.3 persen keluarga termasuk kategori keluarga miskin. Hasil uji statistik menunjukkan adanya perbedaan yang signifikan antar ratarata lama pendidikan suami dan istri serta pendapatan perkapita pada kelompok PKH dengan kelompok PNPM, Raksa Desa dan PUAP $(p<0.05)$. Persentase tertinggi $(35.7 \%)$ suami bekerja sebagai buruh dan istri (38.0\%) sebagai pedagang (Tabel 2). 
Tabel 2. Karakteristik Keluarga berdasarkan Kelompok Program Pemberdayaan

\begin{tabular}{|c|c|c|c|c|c|}
\hline Peubah & PNPM & PKH & Raksa Desa & PUAP & Total \\
\hline 1. Umur Istri (thn) & $36.79 \pm 8.69$ & $37.71 \pm 9.41$ & $37.81 \pm 8.68$ & $40.45 \pm 12.99$ & $37.49 \pm 9.62$ \\
\hline 2. Umur suami (thn) & $42.31 \pm 8.53$ & $45.59 \pm 11.27$ & $43.13 \pm 7.71$ & $44.86 \pm 13.57$ & $43.75 \pm 10.00$ \\
\hline 3. J umlah anggota keluarga (orang) & $4.99 \pm 1.56$ & $5.81 \pm 1.72$ & $5.32+10.90$ & $5.00 \pm 1.45$ & $5.32+1.68$ \\
\hline 5. Pendidikan suami (thn) & $6.85 \pm 3.23$ & $4.61 \pm 2.62$ & $8.39 \pm 3.02$ & $8.05 \pm 3.95$ & $6.30 \pm 3.34$ \\
\hline \multicolumn{6}{|l|}{ 6. Pendapatan perkapita } \\
\hline <Rp 178835 (miskin) & $18.6 \%$ & $83.2 \%$ & $6.5 \%$ & $31.8 \%$ & $41.3 \%$ \\
\hline Rata-rata \pm std (Rp/ Kap/ bulan) & $\begin{array}{r}580588.7 \pm \\
456215.9\end{array}$ & $\begin{array}{r}125028.6 \pm \\
94756.5\end{array}$ & $\begin{array}{r}476278.1 \pm \\
38626.5\end{array}$ & $\begin{array}{r}512795.1 \pm \\
547693.6\end{array}$ & $\begin{array}{r}402355.3 \pm \\
424117.0\end{array}$ \\
\hline \multicolumn{6}{|l|}{ 7. Pekerjaan istri } \\
\hline Tidak bekerja (IRT) & $20.0 \%$ & $58.9 \%$ & $38.7 \%$ & $45.5 \%$ & $37.7 \%$ \\
\hline Petani & $0.7 \%$ & $1.9 \%$ & $0.0 \%$ & $4.5 \%$ & $1.3 \%$ \\
\hline Pedagang & $62.1 \%$ & $8.4 \%$ & $38.7 \%$ & $27.3 \%$ & $38.0 \%$ \\
\hline Wiraswasta & $10.7 \%$ & $0.0 \%$ & $3.2 \%$ & $13.6 \%$ & $6.3 \%$ \\
\hline Lainnya & $2.9 \%$ & $2.8 \%$ & $3.2 \%$ & $4.5 \%$ & $3.0 \%$ \\
\hline \multicolumn{6}{|l|}{ 8. Pekerjaan suami } \\
\hline Tidak bekerja & $8.6 \%$ & $12.1 \%$ & $3.2 \%$ & $13.6 \%$ & $9.7 \%$ \\
\hline Petani & $2.9 \%$ & $2.8 \%$ & $3.2 \%$ & $18.2 \%$ & $4.0 \%$ \\
\hline Pedagang & $32.1 \%$ & $18.7 \%$ & $48.4 \%$ & $22.7 \%$ & $28.3 \%$ \\
\hline PNS & $1.4 \%$ & $0.0 \%$ & $6.5 \%$ & $0.0 \%$ & $1.3 \%$ \\
\hline Buruh & $25.0 \%$ & $59.8 \%$ & $16.1 \%$ & $13.6 \%$ & $35.7 \%$ \\
\hline Karyawan & $8.6 \%$ & $0.9 \%$ & $3.2 \%$ & $13.6 \%$ & $5.7 \%$ \\
\hline Sopir & $7.1 \%$ & $2.8 \%$ & $9.7 \%$ & $9.1 \%$ & $6.0 \%$ \\
\hline Wiraswasta & $10.7 \%$ & $0.9 \%$ & $6.5 \%$ & $9.1 \%$ & $6.7 \%$ \\
\hline
\end{tabular}

\section{Ketahanan Pangan Keluarga}

Indikator ketahanan pangan yang digunakan adalah ketersediaan pangan, stabilitas ketersediaan pangan, kualitas pangan dan tingkat konsumsi gizi keluarga.

\section{Ketersediaan Pangan Pokok}

Menurut Pusat Penelitian Kependudukan (PPK) LIPI (2004) ketersediaan pangan di rumah tangga mengacu pada pangan yang cukup dan tersedia dalam jumlah yang dapat memenuhi kebutuhan konsumsi rumah tangga. LIPI menggunakan indikator ketersediaan pangan wilayah berdasarkan hitungan hari yaitu jika suatu wilayah memiliki ketersediaan pangan lebih dari 240 hari maka ketersediaan pangan dikatakan cukup, dan jika memiliki ketersediaan pangan antara 1-239 maka dikatakan kurang.

Ketersediaan pangan pokok keluarga pada penelitian ini dilihat dari jangka waktu pembelian pangan pokok bagi keluarga yang terdiri dari harian, mingguan, atau bulanan.
Lebih dari setengah (63.7\%) keluarga memiliki kebiasaan membeli pangan pokok harian (Tabel 3). Pola yang sama juga ditemukan di semua kelompok pemberdayaan. Pada kelompok PKH jumlah keluarga yang membeli pangan pokok harian sebanyak 79.4 persen dan pada kelompok PUAP 91.0 persen. Keadaan tersebut menunjukkan bahwa sebagian besar keluarga memiliki ketersediaan pangan pokok harian sehingga dapat dikatakan bahwa ketersediaan pangan pokok pada sebagian besar keluarga masih kurang terjamin. Hasil penelitian Varendra (2007) menunjukkan bahwa ada kecenderungan masyarakat di desa yang sebagian besar bekerja di sektor pertanian tidak menyimpan pangan pokok. Mereka cenderung membeli beras bersifat harian, sehingga sangat rentan terhadap perubahan harga pangan. Masih banyaknya petani yang tidak menyimpan bahan pangan bukan semata-mata hasil panen yang rendah, tetapi karena keinginan untuk mendapatkan uang tunai segera setelah panen untuk berbagai keperluan yang mendesak.

Tabel 3. Sebaran Keluarga berdasarkan Kebiasaan Membeli Pangan Pokok

\begin{tabular}{|c|c|c|c|c|c|c|c|c|c|c|}
\hline \multirow{2}{*}{ Kebiasaan Membeli Pangan Pokok } & \multicolumn{2}{|c|}{ PNPM } & \multicolumn{2}{|c|}{ PKH } & \multicolumn{2}{|c|}{ Raksa Desa } & \multicolumn{2}{|c|}{ PUAP } & \multicolumn{2}{|c|}{ Total } \\
\hline & $\mathbf{n}$ & $\%$ & $\mathbf{n}$ & $\%$ & $\mathbf{n}$ & $\%$ & $\mathbf{n}$ & $\%$ & $\mathbf{n}$ & $\%$ \\
\hline Harian (Ketersediaan tidak terjamin) & 74 & 52.9 & 85 & 79.4 & 12 & 38.7 & 20 & 91.0 & 191 & 63.7 \\
\hline Mingguan (Ketersediaan kurang terjamin) & 52 & 37.1 & 18 & 16.8 & 11 & 35.5 & 1 & 4.5 & 82 & 27.3 \\
\hline Bulanan (Ketersediaan terjamin) & 14 & 10.0 & 4 & 3.8 & 8 & 25.8 & 1 & 4.5 & 27 & 9.0 \\
\hline Total & 140 & 100.0 & 107 & 100.0 & 31 & 100.0 & 22 & 100.0 & 300 & 100.0 \\
\hline
\end{tabular}


Walaupun demikian ditemukan juga yang membeli pangan pokok secara mingguan dan paling banyak ditemukan pada kelompok PNPM (37.1\%), sedangkan secara bulanan paling banyak ditemukan di kelompok Raksa Desa (25.8\%).

\section{Stabilitas Ketersediaan Pangan}

Frekuensi makan sebenarnya dapat menggambarkan keberlanjutan ketersediaan pangan dalam rumah tangga. Dalam satu rumah tangga, salah satu cara untuk mempertahankan ketersediaan pangan dalam jangka waktu tertentu adalah dengan mengurangi frekuensi makan. Penelitian yang dilakukan LIPI di beberapa daerah di Jawa Barat juga menemukan bahwa mengurangi frekuensi makan merupakan salah satu strategi rumah tangga untuk memperpanjang ketahanan pangan mereka. Penelitian tersebut juga menemukan bahwa rumah tangga yang memiliki persediaan makanan pokok pada umumnya makan sebanyak 3 kali per hari. Jika mayoritas rumah tangga di satu desa, misalnya, hanya makan dua kali per hari, kondisi ini semata-mata merupakan suatu strategi rumah tangga agar persediaan makanan pokok mereka tidak segera habis, karena dengan frekuensi makan tiga kali sehari, kebanyakan rumah tangga tidak bisa bertahan untuk tetap memiliki persediaan makanan pokok hingga panen berikutnya (PPK-LIPI 2004).

Mengacu pada penelitian tersebut maka stabilitas ketersediaan pangan pada penelitian ini diukur berdasarkan frekuensi makan keluarga per hari. Secara keseluruhan persentase tertinggi (58.0\%) keluarga memiliki kebiasaan makan dalam keluarganya dua kali per hari (Tabel 4). Pola yang sama juga ditemukan di semua kelompok pemberdayaan. Kebiasaan makan dua kali per hari lebih banyak ditemu- kan pada kelompok PKH dan PUAP, masingmasing sebanyak 63.6 persen. Sedangkan kebiasaan makan tiga kali per hari lebih banyak ditemukan pada kelompok PNPM (46.4\%) dan Raksa Desa (41.9\%). Kondisi tersebut menunjukkan bahwa ketersediaan pangan yang kurang stabil lebih banyak ditemukan pada kelompok PKH dan Raksa Desa, sedangkan ketersediaan yang stabil lebih banyak ditemukan di kelompok PNPM dan Raksa Desa. Hal ini disebabkan karena secara ekonomi kelompok PNPM dan Raksa Desa lebih tinggi dibandingkan dengan PKH dan PUAP. Menurut Tabor et al. (2000) determinan dari ketahanan pangan rumah tangga adalah daya beli atau pendapatan untuk memenuhi biaya hidup. Semakin tinggi daya beli atau pendapatan suatu rumah tangga maka ketahanan pangannya semakin baik.

\section{Kualitas Pangan}

Persentase tertinggi (48.6\%) keluarga mengonsumsi kualitas pangan yang baik (Tabel 5). Hal ini berarti keragaman dan jenis pangan yang dikonsumsi oleh keluarga relatif baik. Walaupun demikian masih ditemukan keluarga yang mengkonsumsi pangan yang kurang baik (25.4\%) dan tidak baik (26.0\%) yang menyebar di seluruh kelompok pemberdayaan.

Jika dilihat berdasarkan kelompok pemberdayaan maka kelompok PNPM dan Raksa Desa memiliki kualitas pangan yang dikonsumsi lebih baik dibandingkan PKH dan PUAP. Kualitas konsumsi pangan keluarga yang tidak baik lebih banyak ditemukan pada kelompok PKH (33.6\%) dan PUAP (31.8\%). Menurut Ariani dan Purawantini (2005) walaupun secara kuantitas terpenuhi namun pangan yang dikonsumsi kurang beraneka ragam dapat berdampak negatif terhadap pertumbuhan fisik dan kecerdasan manusia. Hal yang sama juga disampaikan oleh Soekirman (2000) bahwa kekurangan terhadap

Tabel 4. Sebaran Keluarga berdasarkan Frekuensi Makan per Hari

\begin{tabular}{|c|c|c|c|c|c|c|c|c|c|c|}
\hline \multirow{2}{*}{ Frekuensi makan/hari } & \multicolumn{2}{|c|}{ PNPM } & \multicolumn{2}{|c|}{ PKH } & \multicolumn{2}{|c|}{ Raksa Desa } & \multicolumn{2}{|c|}{ PUAP } & \multicolumn{2}{|c|}{ Total } \\
\hline & $\mathbf{n}$ & $\%$ & $\mathbf{n}$ & $\%$ & $\mathbf{n}$ & $\%$ & $\mathbf{n}$ & $\%$ & $\mathbf{n}$ & $\%$ \\
\hline 1 kali (tidak stabil) & 1 & 0.7 & 1 & 0.9 & 0 & 0.0 & 0 & 0.0 & 2 & 0.7 \\
\hline 2 kali (kurang stabil) & 74 & 52.9 & 68 & 63.6 & 18 & 58.1 & 14 & 63.6 & 174 & 58.0 \\
\hline 3 kali (stabil) & 65 & 46.4 & 38 & 35.5 & 13 & 41.9 & 8 & 36.4 & 124 & 41.3 \\
\hline Total & 140 & 100.0 & 107 & 100.0 & 31 & 100.0 & 22 & 100 & 300 & 100.0 \\
\hline
\end{tabular}

Tabel 5. Sebaran Keluarga berdasarkan Kualitas Pangan yang Dikonsumsi

\begin{tabular}{|c|c|c|c|c|c|c|c|c|c|c|}
\hline \multirow{2}{*}{ Kualitas pangan } & \multicolumn{2}{|c|}{ PNPM } & \multicolumn{2}{|c|}{ PKH } & \multicolumn{2}{|c|}{ Raksa Desa } & \multicolumn{2}{|c|}{ PUAP } & \multicolumn{2}{|c|}{ Total } \\
\hline & $\mathbf{n}$ & $\%$ & $\mathbf{n}$ & $\%$ & $\mathbf{n}$ & $\%$ & $\mathbf{n}$ & $\%$ & $\mathbf{n}$ & $\%$ \\
\hline Tidak baik (tidak beragam) & 31 & 22.1 & 36 & 33.6 & 4 & 12.9 & 7 & 31.8 & 78 & 26.0 \\
\hline Kurang baik (kurang beragam) & 22 & 15.7 & 42 & 39.3 & 7 & 22.6 & 5 & 22.7 & 76 & 25.4 \\
\hline Baik (beragam) & 87 & 62.2 & 29 & 27.1 & 20 & 64.5 & 10 & 45.5 & 146 & 48.6 \\
\hline Total & 140 & 100.0 & 107 & 100.0 & 31 & 100.0 & 22 & 100.0 & 300 & 100.0 \\
\hline
\end{tabular}


satu atau beberapa jenis pangan akan mengakibatkan kekurangan zat-zat gizi tertentu, sedangkan konsumsi pangan yang berimbang akan menghindari kekurangan atau kelebihan gizi serta penyakit yang menyertainya.

\section{Tingkat Konsumsi Energi Keluarga}

Menurut Dewan Ketahanan Pangan (2006) jika rumah tangga mengkonsumsi kurang dari 70 persen dari angka kecukupan energi dikategorikan sangat rawan pangan. Berdasarkan hal tersebut maka kategori tingkat konsumsi energi dikategorikan menjadi tiga kelompok yaitu baik/ cukup $100 \%$ dari AKE), kurang (70-99\% dari AKE) dan sangat kurang (<70\% dari AKE).

Persentase tertinggi (42.0\%) keluarga memiliki tingkat konsumsi energi perkapita antara 70-99 persen dari angka kecukupan energi yang dianjurkan, yang berarti tergolong tingkat konsumsi energi per kapita masih kurang (Tabel 6). Selain itu juga masih ditemukan sebanyak 28.7 persen yang termasuk sangat kurang dan 29.3 persen memiliki tingkat konsumsi energi yang cukup (Tabel 6).

Hampir di seluruh kelompok pemberdayaan, tingkat konsumsi energi perkapitanya termasuk kurang. Hal yang berbeda dengan kelompok Raksa Desa, persentase tertinggi keluarga memiliki tingkat konsumsi energi per kapita yang sangat kurang. Tingkat konsumsi energi perkapita yang termasuk kategori cukup paling banyak ditemukan pada kelompok $\mathrm{PKH}$ yaitu 34.3 persen dan terendah di kelompok PUAP (9.1\%). Hasil penelitian Ariani dan Purawantini (2005) menunjukkan bahwa di pedesaan dengan tingkat pendapatan lebih rendah dibandingkan perkotaan memiliki tingkat konsumsi energi lebih tinggi dibandingkan perkotaan. Fenomena ini menunjukkan bahwa pada pendapatan yang lebih rendah, keluarga akan memprioritaskan pada pangan yang har- ganya murah, seperti pangan sumber energi, kemudian dengan semakin meningkatnya pendapatan akan terjadi perubahan konsumsi yaitu dari pangan yang harga murah beralih ke harga pangan mahal, yaitu sumber protein. Mengacu pada hasil penelitian Ariani dan Purawanti (2005) maka lebih banyaknya tingkat konsumsi energi yang cukup pada kelompok PKH disebabkan sebagian besar (83.2\%) keluarga kelompok PKH tergolong keluarga miskin dan tentunya memprioritaskan pangan yang murah yaitu sumber energi seperti beras.

Berdasarkan indikator ketahanan pangan secara keseluruhan maka persentase tertinggi (52.0\%) ketahanan pangan keluarga termasuk kategori rentan dan ditemukan sebanyak 37.3 persen kategori kurang pangan (Tabel 7). Ketahanan pangan keluarga dengan kategori tahan hanya dicapai oleh 10.7 persen keluarga. Berdasarkan kelompok pemberdayaan maka lebih dari setengah keluarga pada kelompok PKH (50.5\%) dan PUAP (63.6\%) memiliki ketahanan pangan keluarga kategori kurang pangan. J umlah tersebut jauh lebih banyak dibandingkan kelompok PNPM (25.0\%) dan Raksa Desa (29.0\%). Rentan pangan lebih banyak di temukan pada kelompok PNPM (60.0\%) dan Raksa Desa (61.3\%). Persentase tertinggi keluarga yang memiliki kategori tahan pangan ditemukan pada kelompok PNPM (15.0\%).

Hasil penelitian Purwantini et al. (2001) yang termasuk kelompok rentan pangan adalah kelompok yang secara ekonomi kurang sejahtera, namun dari sisi konsumsi energi memenuhi kecukupan. Kelompok tersebut memiliki kebiasaan makan sumber karbohidrat yang relatif lebih tinggi dibandingkan kelompok lainnya. Sedangkan kelompok kurang pangan adalah kelompok yang secara ekonomi mampu mengkonsumsi pangan, tapi dari sisi konsumsi energi kurang memenuhi kecukupan.

Tabel 6. Sebaran Keluarga berdasarkan Tingkat Konsumsi Energi per Kapita

\begin{tabular}{|c|c|c|c|c|c|c|c|c|c|c|}
\hline \multirow{2}{*}{$\begin{array}{c}\text { Kategori Tingkat Konsumsi } \\
\text { Energi per Kapita }\end{array}$} & \multicolumn{2}{|c|}{ PNPM } & \multicolumn{2}{|c|}{ PKH } & \multicolumn{2}{|c|}{ Raksa Desa } & \multicolumn{2}{|c|}{ PUAP } & \multicolumn{2}{|c|}{ Total } \\
\hline & $\mathbf{n}$ & $\%$ & $\mathbf{N}$ & $\%$ & $\mathbf{n}$ & $\%$ & $\mathbf{n}$ & $\%$ & $\mathbf{n}$ & $\%$ \\
\hline$<70 \%$ (sangat kurang) & 40 & 28.6 & 22 & 20.6 & 14 & 45.2 & 10 & 45.4 & 86 & 28.7 \\
\hline 70-99\%(kurang) & 60 & 42.8 & 45 & 42.1 & 11 & 35.4 & 10 & 45.5 & 126 & 42.0 \\
\hline$\geq 100 \%$ (cukup) & 40 & 28.6 & 40 & 34.3 & 6 & 19.4 & 2 & 9.1 & 88 & 29.3 \\
\hline Total & 140 & 100.0 & 107 & 100.0 & 31 & 100.0 & 22 & 100.0 & 300 & 100.0 \\
\hline
\end{tabular}

Tabel 7. Sebaran Keluarga berdasarkan Kategori Ketahanan Pangan Keluarga

\begin{tabular}{|c|c|c|c|c|c|c|c|c|c|c|}
\hline \multirow{2}{*}{ Kategori } & \multicolumn{2}{|c|}{ PNPM } & \multicolumn{2}{|c|}{ PKH } & \multicolumn{2}{|c|}{ Raksa Desa } & \multicolumn{2}{|c|}{ PUAP } & \multicolumn{2}{|c|}{ Total } \\
\hline & $\mathbf{n}$ & $\%$ & $\mathbf{n}$ & $\%$ & $\mathbf{n}$ & $\%$ & $\mathbf{n}$ & $\%$ & $\mathbf{n}$ & $\%$ \\
\hline Kurang pangan (skor 5-7) & 35 & 25.0 & 54 & 50.5 & 9 & 29.0 & 14 & 63.6 & 112 & 37.3 \\
\hline Rentan pangan (skor 8-10) & 84 & 60.0 & 45 & 42.1 & 19 & 61.3 & 8 & 36.4 & 156 & 52.0 \\
\hline Tahan pangan (skor 11-13) & 21 & 15.0 & 8 & 7.5 & 3 & 9.7 & 0 & 0.0 & 32 & 10.7 \\
\hline Total & 140 & 100.0 & 107 & 100.0 & 31 & 100.0 & 22 & 100.0 & 300 & 100.0 \\
\hline
\end{tabular}




\section{Faktor-Faktor yang Mempengaruhi Ketahan- an Pangan Keluarga}

Hasil analisis regresi berganda menunjukkan bahwa faktor yang berpengaruh nyata terhadap ketahanan pangan keluarga adalah pendapatan perkapita, jumlah anggota keluarga dan jumlah aset yang dimiliki (Tabel 8), dengan nilai adjusted $\mathrm{R}$ square 0.108 . Hal ini berarti 10.8 persen peubah-peubah bebas tersebut mempengaruhi ketahanan keluarga, dan sisanya (89.2\%) dipengaruhi faktor lain yang tidak diteliti dalam penelitian ini.

Hasil analisis menunjukkan bahwa pendapatan perkapita berpengaruh positif dan sangat nyata terhadap ketahanan pangan keluarga $(a<0.01)$. Setiap kenaikan satu poin tingkat pendapatan maka akan menaikkan ketahanan pangan 0.453 poin (Tabel 8). Hal ini sesuai dengan pendapat Boius dan Hunt (1999) bahwa resiko tidak memiliki akses terhadap pangan berkaitan dengan pandapatan rumah tangga. Rose (1999) menyatakan bahwa pendapatan rumah tangga merupakan determinan penting terhadap ketidaktahanan pangan rumah tangga. Hal yang sama diungkapkan oleh Braun et al. (1992); Lorenza dan Sanjur (1999) bahwa akses terhadap pangan pada tingkat rumah tangga ditentukan oleh tingkat pendapatan rumah tangga, di mana pendapatan rumah tangga ini merupakan proxy untuk daya beli rumah tangga. Menurut Smith (2002), FAO (1996) bahwa ketidak-tahanan pangan banyak terjadi pada negara-negara sedang berkembang, dan pada umumnya disebabkan oleh kemiskinan, yang menyebabkan ketidakmampuan penduduk untuk meningkatkan akses terhadap pangan. Oleh karena itu, Suhardjo (1996) menyatakan bahwa pendapatan rumah tangga dapat dijadikan indikator bagi ketahanan pangan rumah tangga, karena penda- patan merupakan salah satu kunci utama bagi rumah tangga untuk mengakses pangan.

Jumlah anggota keluarga berpengaruh negatif dan nyata terhadap ketahanan pangan keluarga $(\mathrm{a}<0.01)$. Setiap kenaikan satu poin jumlah anggota keluarga maka akan menurunkan ketahanan keluarga sebanyak 0.120 poin. Menurut Suhardjo (1989) pada keluarga miskin, jumlah anggota keluarga yang terlalu besar seringkali mempunyai masalah dalam hal pemenuhan kebutuhan pokok keluarga, sehingga kondisi ini akan memperbesar tingkat stres keluarga. Hasil penelitian Purwantini et al. (2001) menemukan bahwa rumah tangga rawan pangan dicirikan oleh pendidikan suami dan istri yang rendah, dan jumlah anggota keluarga yang tinggi. Menurut Rose (1999) ukuran rumah tangga merupakan salah satu faktor yang menentukan tingkat ketahanan pangan. Ukuran rumah tangga yang lebih besar memerlukan konsumsi pangan lebih banyak, oleh karena itu diperlukan kebutuhan pangan yang lebih besar.

Jumlah aset yang dimiliki keluarga berpengaruh positif dan nyata terhadap ketahanan keluarga $(a<0.01)$. Setiap kenaikan satu poin jumlah aset yang dimiliki maka akan menaikkan ketahanan keluarga sebanyak 0.294 poin. Menurut Bryant (1990), keluarga yang memiliki aset banyak cenderung lebih sejahtera dibandingkan dengan keluarga yang memiliki aset terbatas. Rothwel (2011) menyatakan bahwa aset merupakan hal yang penting karena aset dapat membantu seseorang menjadi lebih maju dan sebaliknya keterbatasan aset yang dimiliki akan berdampak pada kesulitan ekonomi. Berdasarkan pernyataanpernyataan tersebut dapat dikatakan bahwa keluarga yang memiliki jumlah aset cenderung tidak mengalami kesulitan ekonomi dan lebih sejahtera, dengan demikian ketahanan pangan menjadi lebih terjamin.

Tabel 8. Analisis Regresi Faktor-faktor yang Mempengaruhi Ketahanan Pangan Keluarga

\begin{tabular}{llcccc}
\hline No & \multicolumn{1}{c}{ Peubah bebas } & $\begin{array}{c}\text { Unstandardized } \\
\text { Coefficients }\end{array}$ & $\begin{array}{c}\text { Standardized } \\
\text { Coefficients }\end{array}$ & t & Sig \\
\cline { 3 - 4 } & Beta & & & \\
\hline & Constant & 6.878 & 0.236 & 3.515 & $0.001^{* *}$ \\
1 & Pendapatan/ kapita & 0.453 & -0.119 & -1.983 & $0.048^{*}$ \\
2 & Jumlah anggota keluarga & -0.120 & -0.039 & -0.641 & 0.522 \\
3 & Pendidikan kepala keluarga & -0.020 & 0.059 & 1.017 & 0.310 \\
4 & Umur kepala keluarga & 0.010 & 0.138 & 2.153 & $0.032^{*}$ \\
5 & Jumlah aset & 0.294 & 0.028 & 0.490 & 0.625 \\
\hline
\end{tabular}

Adjusted R Square $=0.108$

* Nyata pada taraf $p<0.05$

** Nyata pada taraf $p \varangle 0.01$ 


\section{KESIMPULAN}

Rata-rata umur istri dan suami masih termasuk usia produktif dengan jumlah anggota termasuk kategori sedang. Tingkat pendidikan istri maupun suami termasuk rendah ( $\mathrm{Ta}$ mat SD). Sebanyak 41.3 persen keluarga termasuk kategori keluarga miskin. Persentase tertinggi (35.7\%) suami bekerja sebagai buruh dan istri (38.0\%) sebagai pedagang.

Persentase tertinggi (52.0\%) ketahanan pangan keluarga termasuk kategori rentan dan ditemukan sebanyak 37.3 persen kategori kurang pangan. Ketahanan pangan keluarga dengan kategori tahan ditemukan sebanyak 10.7 persen keluarga. Berdasarkan kelompok pemberdayaan maka lebih dari setengah keluarga pada kelompok PKH (50.5\%) dan PUAP (63.6\%) memiliki ketahanan pangan keluarga kategori kurang pangan. Rentan pangan lebih banyak di temukan pada kelompok PNPM (60\%) dan Raksa Desa (61.3\%). Persentase tertinggi (15\%) keluarga yang memiliki kategori tahan pangan ditemukan pada kelompok PNPM. Faktor yang berpengaruh nyata terhadap ketahanan pangan keluarga adalah pendapatan perkapita, jumlah anggota keluarga dan jumlah aset yang dimiliki.

Saran yang dapat diberikan adalah perlu adanya pelatihan kewirausahaan bagi anggota keluarga untuk meningkatkan produktivitas anggota keluarga dalam meningkatkan pendapatan Hal ini perlu dilakukan terkait tingkat pendapatan berpengaruh nyata terhadap ketahanan pangan dan sumberdaya alam setempat yang cukup mendukung karena dominan wilayah pertanian.

Selain itu, perlu dilakukan penyuluhan tentang pengetahuan gizi dan keragaman konsumsi pangan untuk mendukung peningkatan ketahanan pangan keluarga. Serta perlu dilakukan pelatihan pengolahan pangan berbasis lokal untuk meningkatkan nilai ekonomi produk lokal dan keanakaragaman pengolahan produk lokal sehingga dapat mendukung peningkatan ketahanan pangan

\section{DAFTAR PUSTAKA}

Ariani M \& Purwantini TB. 2005. Analisis Konsumsi Pangan Rumah Tangga Pasca Krisis Ekonomi di Propinsi Jawa Barat. Puslitbang Sosial Ekonomi Pertanian.
Badan Pusat Statistik. 2010. Berita Resmi Statistik: Profil Kemiskinan di Indonesia Maret 2010.

BKKBN. 1996. Opini Pengembangan Keluarga Sejahtera. J akarta. BKKBN

Bouis dan Hunt. 1999. Linking Food and Nutrition Security: past lesson and future opprtunities. Asian Development Review 17 (12).

Braun, J V Von, Bouis H, Kumar S, \& PandyaLorch R. 1992. Improving Food Security of The Poor: concept, policy and program. International Food Policy Research Institute, Washington DC.

Bryant WK. 1990. The Economic Organization of The Household. University Press, Cambridge.

Dewan Ketahanan Pangan. 2006. Kebijakan Umum Ketahanan Pangan 2006-2009. Departemen Pertanian, Jakarta.

Cahyadi W. 2009. Gizi buruk dan kemiskinan. www. pikiran-rakyat.com [18 Okt 2010].

[FAO]. 1996. World Food Summit 13-17 November 1996. Food and Agriculture Organization of The United Nations, Rome.

Hurlock EB. 1980. Development Psychology : A Life Span Approach. McGraw-Hill, New York.

Lorenza P \& Sanjur D. 1999. Abbreviated Measures of Food Sufficiency Validly Estimate the Food Security Level of Poor Household: Measuring household food security. Community and International Nutrition American Society for Nutritional Sceineces.

Purwantini TB, R. Handewi PS, \& Marisa Y. 2001. Analisis Ketahanan Pangan Regional dan Tingkat Rumah Tangga (Studi Kasus di Propinsi Sulawesi Utara). Pusat Analisis Sosial Ekonomi dan Kebijakan Pertanian, Bogor.

Pusat Penelitian Kependudukan (PPK) LIPI. 2004. Ketahanan Pangan Rumah Tangga di Pedesaan: Konsep dan Ukuran. LIPI, J akarta. 
Rose D. 1999. Economic Determinants and Dietary Consequences of Food Insecurity in The United States. Community and International Nutrition American Society for Nutritional Sceineces.

Rothwel D. 2011. Exploring Asset and Family Stress. Centre for Research Children and Family. McGill School of Social Work.

Smith LC. 2002. The Use of Household Expenditure Surveys for The Assesment of Food Security. Dalam International Secientific Symposium on Measurement and Assesment of Food Deprivation and Under Nutrition. FAO, Rome.

Soekirman. 2000. Ilmu Gizi dan Aplikasinya. Direktorat Jenderal Pendidikan Tinggi, Departemen Pendidikan Nasional, J akarta.

Sudiman H. 2008. Tantangan Litbang Lintas Disiplin dalam Penanggulangan Masalah Kemiskinan, Kelaparan dan Gizi Kurang di Indonesia. Dalam Orasi Pengukuhan Profesor Riset Bidang Gizi Masyarakat. Departemen Kesehatan RI, J akarta.
Suhardjo. 1989. Berbagai Cara Pendidikan Gizi. Petunjuk Laboratorium. Pusat Antar Universitas Pangan dan Gizi, IPB, Bogor.

1996. Pengertian dan Kerangka Pikir Ketahanan Pangan Rumah Tangga. Dalam Makalah Lokakarya Ketahanan Pangan Rumah Tangga. Yogyakarta.

Supari SF. 2008. Selamatkan Ibu dan Anak Indonesia. Dalam Rakerkesnas. Depkes RI, J akarta.

Suryana A. 2004. Ketahanan Pangan di Indonesia. Dalam Makalah pada Widyakarya Nasional Pangan dan Gizi VIII, J akarta.

Tabor S, Sukirman, \& Martianto D. 2000. Keterkaitan Antara Krisis Ekonomi, Ketahanan Pangan dan Perbaikan Gizi. Dalam Prosiding Widyakarya Nasional Pangan dan Gizi. LIPI, Jakarta.

Varendra MD. 2007. Dampak krisis ekonomi terhadap ketahanan pangan. www.umm. ac.id [6 J un 2011]. 